\title{
Penerapan Model Pembelajaran Student Facilitator And Explaining (SFAE) dalam Meningkatkan Kemampuan Pemahaman dan Hasil Belajar Matematika Materi Sistem Persamaan Linear Dua Variabel pada Siswa Kelas VIII-H SMP Negeri 4 Madiun Tahun Pelajaran 2016/2017
}

\author{
Umi Nurhajati
}

\section{2019 JEMS (Jurnal Edukasi Matematika dan Sains)}

This is an open access article under the CC-BY-SA license (https://creativecommons.org/licenses/bysa/4.0/) ISSN 2337-9049 (print), ISSN 2502-4671 (online)

\begin{abstract}
Abstrak:
Penelitian ini bertujuan untuk menganalisis peningkatan kemampuan pemahaman dan hasil belajar kelas VIII-H melalui penerapan model pembelajaran Student Facilitator and Explaining (SFAE). Untuk meningkatkan kemampuan pemahaman hasil belajar siswa pada mata pelajaran matematika, maka dilakukan penelitian tindakan kelas yang terdiri dari dua siklus. Setiap siklus terdiri dari tahap perencanaan, pelaksanaan, pengamatan dan refleksi. Subjek penelitian ini adalah siswa kelas VIII-H SMP Negeri 4 Madiun Tahun Pelajaran 2016/2017 yang terdiri dari 30 siswa. Instrumen pengumpulan data dalam penelitian ini adalah soal evaluasi untuk ranah kognitif yang dilaksanakan setiap akhir siklus dan lembar observasi untuk kemampuan pemahaman, ranah afektif dan psikomotorik. Hasil penelitian menunjukkan adanya peningkatan kemampuan pemahaman matematika pada siklus I diperoleh presentase rata-rata siswa sebesar $64,06 \%$ dengan kriteria cukup meningkat menjadi $76,35 \%$ dengan kriteria baik. Penerapan model pembelajaran Student Facilitator and Explaining (SFAE) dapat meningkatkan kemampuan pemahaman dan hasil belajar. Saran yang berkaitan dengan penelitian ini yaitu guru hendaknya memberi motivasi atau penghargaan berupa nilai terhadap tugas siswa, sehingga siswa termotivasi untuk belajar karena merasa dihargai. Model pembelajaran Student Facilitator and Explaining (SFAE) dapat dijadikan alternatif untuk memvariasikan model pembelajaran. Untuk peneliti lain yaitu hendaknya dapat meneliti aspek hasil belajar afektif dan psikomotorik yang lainnya.
\end{abstract}

Kata Kunci : Student Facilitator and Explaining (SFAE); Kemampuan Pemahaman; Hasil Belajar
Abstract:

This study aims to analyze the increase in the ability of understanding and learning outcomes of class VIII-H through the application of the Student Facilitator and Explaining (SFAE) learning model. To improve the ability to understand student learning outcomes in mathematics, class action research was conducted consisting of two cycles. Each cycle consists of planning, implementing, observing, and reflecting. The subjects of this study were students of class VIII-H of SMP Negeri 4 Madiun in the 2016/2017 Academic Year consisting of 30 students. Data collection instruments in this study were a matter of evaluation for the cognitive domain carried out at the end of each cycle and observation sheets for comprehension, affective, and psychomotor domains. The results showed an increase in the ability to understand mathematics in the first cycle obtained an average percentage of students of $64.06 \%$ with sufficient criteria to increase to $76.35 \%$ with good criteria. The application of the Student Facilitator and Explaining (SFAE) learning model can improve the ability of understanding and learning outcomes. Suggestions relating to this research are that teachers should provide motivation or appreciation in the form of grades on student assignments, so students are motivated to learn because they feel valued. Student Facilitator and Explaining (SFAE) learning models can be used as an alternative to varying learning models. For other researchers, that is, they should be able to examine other aspects of affective and psychomotor learning outcomes.

Keywords : Student Facilitator and Explaining (SFAE); Understanding Ability; Learning Outcome

\section{Pendahuluan}

Pendidikan merupakan faktor utama dalam pembentukan pribadi manusia. Pendidikan sebagai suatu peristiwa yang memiliki norma menurut ukuran normatif (Sardiman, 2007). Se- 
bagai suatu kegiatan yang sadar akan tujuan, maka dalam pelaksanaannya berada dalam suatu proses yang berkesinambungan dalam setiap jenis dan jenjang pendidikan. Semuanya berkaitan dalam suatu sistem pendidikan yang integral.

Pemahaman konsep matematika merupakan salah satu hal yang terpenting dalam pembelajaran. Pemahaman konsep membuat siswa lebih mudah dalam menyelesaikan permasalahan karena siswa akan mampu mengaitkan serta memecahkan permasalahan tersebut dengan berbekal konsep yang sudah dipahaminya. Sebaliknya, jika siswa kurang memahami suatu konsep yang diberikan maka siswa akan cenderung mengalami kesulitan dalam menggunakan dan memilih prosedur atau operasi tertentu serta mengaplikasikan konsep dan algoritma pemecahan masalah. Menyadari pentingnya pemahaman konsep dalam pembelajaran matematika, maka pembelajaran tersebut perlu direncanakan sedemikian rupa sehingga pada akhir pembelajaran siswa dapat memahami konsep yang dipelajarinya.

Belajar matematika memerlukan pemahaman terhadap konsep-konsep pada teorema atau rumus. Pemahaman konsep terhadap setiap materi yang diajarkan guru penting dimiliki setiap siswa karena dapat membantu proses mengingat dan membuat lebih mudah dalam mengerjakan soal-soal matematika yang memerlukan banyak rumus. Pemahaman terbentuk tidak hanya dengan mendengarkan penjelasan dari guru, langsung menerima materi dari guru, penghafalan rumus-rumus matematika dan langkah-langkah penyelesaian soal melainkan dengan memahami makna dari konsep yang dipelajari. Hasil belajar merupakan perubahan perilaku yang diperoleh pembelajar setelah mengalami aktivitas belajar. Hasil belajar siswa tidaklah sama, ada yang baik dan ada yang kurang baik. Kebanyakan siswa mengalami masalah dalam belajar, sehingga masalah tersebut berdampak terhadap hasil belajar siswa yang rendah.

Faktor Ekstern yang mempengaruhi hasil belajar salah satunya yaitu faktor model pembelajaran. Menurut Arends, sebagaimana dikutip oleh Suprijono (2009), model pembelajaran mengacu pada pendekatan yang akan digunakan, termasuk di dalamnya tujuan-tujuan pembelajaran, tahap-tahap dalam kegiatan pembelajaran, lingkungan pembelajaran, dan pengelolaan kelas. Selain siswa, unsur terpenting yang ada dalam kegiatan pembelajaran adalah guru. Seorang guru dalam menyampaikan materi perlu memilih model yang sesuai dengan keadaan kelas atau siswa sehingga siswa merasa tertarik untuk mengikuti pelajaran yang diajarkan. Model mengajar guru yang kurang baik akan mempengaruhi hasil belajar siswa menjadi kurang baik pula. Misalkan guru kesehariannya dalam mengajar biasa menggunakan model ceramah, siswa akan menjadi bosan, mengantuk, hanya mencatat, akhirnya siswa menjadi pasif. Jelaslah bahwa model pembelajaran itu mempengaruhi hasil belajar. Oleh karena itu, seorang guru harus yang progresif berani mencoba model-model pembelajaran yang baru untuk meningkatkan keaktifan siswa. Dalam kegiatan belajar mengajar, seorang guru sebaiknya memposisikan seorang siswa sebagai insan yang perlu dihargai potensinya, sehingga hendaknya seorang siswa diberi kesempatan untuk aktif sehingga dapat mengembangkan potensinya. Maka dari itu, proses belajar mengajar perlu suasana yang akrab, terbuka dan saling menghargai.

Siswa dituntut untuk lebih memahami materi secara konsep daripada menghafal. Untuk mengatasi kesulitan tersebut maka guru diharapkan mampu menggunakan model pembelajaran yang membuat siswa aktif dan memudahkan siswa untuk memahami materi. Dalam setiap kegiatan belajar mengajar, guru perlu menggunakan model pembelajaran yang bervariasi untuk memudahkan siswa belajar yang tentunya disesuaikan dengan kondisi siswa dan kondisi materi yang akan diajarkan sehingga diharapkan hasil belajar siswa baik.

Kepasifan siswa salah satunya dikarenakan model pembelajaran yang digunakan guru bersifat monoton, guru sering menggunakan model ceramah tanpa melibatkan keaktifan siswa. Selain itu, setiap ada penugasan baik tugas rumah maupun tugas sekolah tidak ada penilaian oleh guru. Tidak adanya penilaian terhadap tugas-tugas tersebut mengakibatkan 
siswa pasif, karena mereka merasa tidak penting belajar dan mengerjakan tugas kalau tidak dinilai. Guru hendaknya menggunakan model pembelajaran yang melibatkan keaktifan siswa dalam proses pembelajaran, sehingga diharapkan siswa dapat mengembangkan potensi karena adanya timbal balik/komunikasi dua arah antara guru dan siswa dan hasil belajar siswa menjadi lebih baik. Jadi model pembelajaran yang digunakan setiap pertemuan tidak monoton hanya ceramah, tanya jawab, penugasan, dll. Akan tetapi, dalam setiap pertemuan menggunakan model pembelajaran yang bervariasi, yang tentunya disesuaikan dengan situasi dan kondisi siswa dan materi. Terkait dengan permasalahan-permasalahan di atas maka untuk mengatasi masalah-masalah tersebut peneliti menawarkan strategi model pembelajaran yaitu model pembelajaran Student Facilitator and Explaining (SFAE).

Rachmad Widodo (2009) model pembelajaran Student Facilitator and Explaining (SFAE) merupakan model pembelajaran dimana siswa/peserta didik belajar mempresentasikan ide/pendapat pada rekan peserta didik lainnya. Model pembelajaran Student Facilitator and Explaining (SFAE) merupakan salah satu model pembelajaran kooperatif yang melibatkan keaktifan siswa dalam proses pembelajaran. Model pembelajaran kooperatif dengan menggunakan kelompok-kelompok kecil dengan jumlah anggota tiap kelompok 4-5 siswa secara heterogen (Trianto, 2007). Model pembelajaran Student Facilitator and Explaining merupakan metode pembelajaran aktif. Hakikatnya pembelajaran aktif untuk mengarahkan atensi peserta didik terhadap materi yang dipelajarinya. Berdasarkan latar belakang tersebut, peneliti akan melakukan sebuah penelitian tindakan kelas untuk meningkatkan kemampuan pemahaman dan hasil belajar siswa dengan menerapkan metode yang mungkin dapat meningkatkan hasil belajar yaitu metode pembelajaran Student Facilitator and Explaining (SFAE).

\section{Metode}

Dalam melaksanakan penelitian ini, peneliti mengambil lokasi penelitian di SMP Negeri 4 Kota Madiun, yang beralamat di Jl. Abdul Rakhman Saleh no. 3 Kota Madiun. Penelitian tindakan kelas ini akan dilakukan pada bulan Agustus sampai dengan bulan Oktober 2016 pada Semester Ganjil Tahun Pelajaran 2016/2017. Subyek penelitian yang digunakan dalam penelitian ini adalah siswa kelas VIII-H SMP Negeri 4 Madiun Tahun Pelajaran 2016/2017 dengan jumlah 30 siswa, terdiri dari 14 siswa laki-laki dan 16 siswa perempuan

Teknik pengumpulan data yang digunakan dalam penelitian tindakan kelas ini adalah metode observasi, dokumentasi dan tes. Prosedur penelitian tindakan kelas yang akan dilakukan oleh peneliti direncanakan dalam dua siklus. Masing-masing siklus dilaksanakan dalam beberapa tahap yaitu perencanaan tindakan, pelaksanaan tindakan, observasi dan interpretasi serta analisis dan refleksi.

\section{Hasil dan Pembahasan}

\section{Siklus I}

1. Kemampuan Pemahaman Siswa

Berikut data hasil kemampuan pemahaman siswa pada pembelajaran matematika dengan model pembelajaran Student Facilitator and Explaining (SFAE) pada siklus I. 
Tabel 4.1 Data Kemampuan Pemahaman Siswa Siklus I

\begin{tabular}{clcccc}
\hline \multirow{2}{*}{ No. } & \multicolumn{1}{c}{ Indikator } & \multicolumn{2}{c}{ P1 } & \multicolumn{2}{c}{ P2 } \\
\cline { 3 - 6 } & Skor & \multicolumn{2}{c}{ Skor } & $\%$ \\
\hline 1. & Memberi contoh dan non contoh dari konsep & 213 & 59,17 & 232 & 64,44 \\
\hline 2. & Menyatakan ulang sebuah konsep & 207 & 57,50 & 226 & 62,78 \\
\hline 3. & $\begin{array}{l}\text { Mengklasifikasikan obyek-obyek menurut sifat-sifat } \\
\text { tertentu (sesuai dengan konsepnya) }\end{array}$ & 240 & 57,14 & 268 & 63,81 \\
\hline 4. & $\begin{array}{l}\text { Menyajikan konsep dalam berbagai bentuk representasi } \\
\text { matematis }\end{array}$ & 271 & 64,52 & 285 & 67,86 \\
\hline 5. & $\begin{array}{l}\text { Mengembangkan syarat perlu dan syarat cukup suatu } \\
\text { konsep }\end{array}$ & 302 & 62,92 & 308 & 64,17 \\
\hline 6. & $\begin{array}{l}\text { Menggunakan, memanfaatkan, dan memilih prosedur } \\
\text { atau operasi tertentu }\end{array}$ & 313 & 65,21 & 321 & 66,88 \\
\hline 7. & $\begin{array}{l}\text { Mengaplikasikan konsep atau algoritma pemecahan } \\
\text { masalah }\end{array}$ & 323 & 67,29 & 320 & 69,79 \\
\hline & Skor & Rata-rata & $62,30 \%$ & \multicolumn{2}{c}{$65,83 \%$} \\
\hline & Kriteria & cukup & \multicolumn{2}{c}{ cukup } \\
\hline
\end{tabular}

Berdasarkan tabel diatas menunjukkan hasil pengamatan kemampuan pemahaman siswa dalam pembelajaran siklus I pertemuan 1 memperoleh kriteria cukup dengan persentase skor jawaban benar 62,30\%. Dari pertemuan 1 tersebut belum mendapat kriteria yang diharapkan. Dari hasil pengamatan siklus I pertemuan 2, kemampuan pemahaman siswa meningkat $65,83 \%$ namun masih dalam kategori cukup.

2. Hasil Belajar Siswa

Hasil belajar ranah kognitif, afektif dan psikomotorik yang diperoleh siswa pada siklus I dapat dilihat pada tabel berikut.

Tabel 4.2 Hasil Belajar Siswa Siklus I

\begin{tabular}{lccc}
\hline \multirow{2}{*}{ Keterangan } & \multicolumn{3}{c}{ Hasil Belajar } \\
\cline { 2 - 4 } & Kognitif & Afektif & Psikomotorik \\
\hline Nilai terendah & 52 & 45 & 42 \\
\hline Nilai tertinggi & 84 & 90 & 83 \\
\hline Rata-rata kelas & 73,60 & 73,00 & 69,72 \\
\hline Ketuntasan klasikal & 66,67 & 63,33 & 60,00 \\
\hline Kategori & cukup & cukup & cukup \\
\hline
\end{tabular}

\section{Siklus II}

1. Kemampuan Pemahaman Siswa

Berikut data hasil kemampuan pemahaman siswa pada pembelajaran matematika dengan model pembelajaran Student Facilitator and Explaining (SFAE) pada siklus II.

Tabel 4.3 Data Kemampuan Pemahaman Siswa Siklus II

\begin{tabular}{clcccc}
\hline \multirow{2}{*}{ No. } & \multirow{2}{*}{ Indikator } & \multicolumn{2}{c}{ P1 } & \multicolumn{2}{c}{ P2 } \\
\cline { 3 - 6 } & Skor & \% & Skor & \% \\
\hline 1. & Memberi contoh dan non contoh dari konsep & 270 & 75,00 & 305 & 84,72 \\
\hline 2. & Menyatakan ulang sebuah konsep & 266 & 73,89 & 306 & 85,00 \\
\hline 3. & $\begin{array}{l}\text { Mengklasifikasikan obyek-obyek menurut sifat-sifat } \\
\text { tertentu (sesuai dengan konsepnya) }\end{array}$ & 299 & 71,19 & \multirow{2}{*}{341} & 81,19 \\
\hline
\end{tabular}


Umi Nurhajati

\begin{tabular}{clcccc}
\hline \multirow{2}{*}{ No. } & \multicolumn{1}{c}{ Indikator } & \multicolumn{2}{c}{ P1 } & \multicolumn{2}{c}{ P2 } \\
\cline { 3 - 6 } & Skor & \% & \multicolumn{2}{c}{ Skor } & \% \\
\hline 4. & $\begin{array}{l}\text { Menyajikan konsep dalam berbagai bentuk representasi } \\
\text { matematis }\end{array}$ & 310 & 73,81 & 338 & 80,48 \\
\hline 5. & $\begin{array}{l}\text { Mengembangkan syarat perlu dan syarat cukup suatu } \\
\text { konsep }\end{array}$ & 337 & 70,21 & 371 & 77,29 \\
\hline 6. & $\begin{array}{l}\text { Menggunakan, memanfaatkan, dan memilih prosedur } \\
\text { atau operasi tertentu }\end{array}$ & 346 & 72,08 & 374 & 77,92 \\
\hline 7. & $\begin{array}{l}\text { Mengaplikasikan konsep atau algoritma pemecahan } \\
\text { masalah }\end{array}$ & 344 & 71,67 & 374 & 77,92 \\
\hline & Skor & Rata-rata & 72,40 & 2409 \\
\hline & Kriteria & baik & \multicolumn{2}{c}{ baik } \\
\hline
\end{tabular}

2. Hasil Belajar Siswa

Tabel 4.4 Hasil Belajar Siswa Siklus II

\begin{tabular}{lccc}
\hline \multirow{2}{*}{ Keterangan } & \multicolumn{3}{c}{ Hasil Belajar } \\
\cline { 2 - 4 } & Kognitif & Afektif & Psikomotorik \\
\hline Nilai terendah & 55 & 65 & 58 \\
\hline Nilai tertinggi & 100 & 90 & 100 \\
\hline Rata-rata kelas & 81,83 & 81,17 & 82,78 \\
\hline Ketuntasan klasikal & 86,67 & 90,00 & 83,33 \\
\hline Kategori & sangat baik & sangat baik & baik \\
\hline
\end{tabular}

Berdasarkan hasil penelitian, indikator pengamatan pada pembelajaran siklus I dan siklus II adalah kemampuan pemahaman siswa dan hasil belajar matematika menggunakan model pembelajaran Student Facilitator and Explaining (SFAE) pada siswa kelas VIII-H SMP Negeri 4 Madiun Tahun Pelajaran 2016/2017. Peningkatan kemampuan pemahaman siswa pada pembelajaran matematika dapat dilihat dari peningkatan presentase jawaban yang benar pada masing-masing siklus. Pada siklus I pertemuan 1 diperoleh presentase rata-rata $62,30 \%$ dengan kriteria cukup, meningkat pada pertemuan 2 yaitu 65,83\% . Pada siklus II pertemuan 1 diperoleh presentase rata-rata $72,40 \%$ dengan kriteria baik dan menjadi $80,30 \%$ pada pertemuan 2 dengan kriteria baik. Hal ini menunjukkan pada siklus II pertemuan 2 telah memenuhi indikator kemampuan pemahaman siswa yaitu mencapai kriteria baik.

Pada siklus I, pertemuan 1 diperoleh hasil tingkat kemampuan pemahaman siswa pada indikator memberi contoh dan non contoh dari konsep sebesar $59,17 \%$ meningkat $5,27 \%$ pada pertemuan 2 menjadi 64,44\%. Indikator menyatakan ulang sebuah konsep pada pertemuan 1 diperoleh data sebesar 57,50\% meningkat 5,28\% pada pertemuan 2 menjadi $62,78 \%$. Perolehan skor pada indikator mengklasifikasikan obyek-obyek menurut sifat-sifat tertentu (sesuai dengan konsepnya) pada pertemuan 1 sebesar $57,14 \%$ meningkat $6,67 \%$ pada pertemuan 2 menjadi $63,81 \%$. Indikator menyajikan konsep dalam berbagai bentuk representasi matematis pada pertemuan 1 sebesar 64,52\% meningkat 3,34\% pada pertemuan 2 menjadi $67,86 \%$. Peningkatan perolehan presentase rata-rata dicapai pada indikator mengembangkan syarat perlu dan syarat cukup suatu konsep pada pertemuan 1 sebesar 62,92\% meningkat 1,25\% menjadi $64,17 \%$ pada pertemuan 2 . Pada pertemuan 1 diperoleh presentase rata-rata sebesar $65,21 \%$ pada indiktor menggunakan, memanfaatkan, dan memilih prosedur atau operasi tertentu meningkat 1,67\% menjadi $66,88 \%$ pada pertemuan 2. Pada pertemuan 1 diperoleh presentase rata-rata sebesar $67,29 \%$ pada indikator mengaplikasikan konsep atau algoritma pemecahan masalah meningkat 1,89\% menjadi $69,79 \%$ pada pertemuan 2 . 
Pada siklus II, pertemuan 1 diperoleh hasil tingkat kemampuan pemahaman siswa pada indikator memberi contoh dan non contoh dari konsep sebesar $75,00 \%$ meningkat $9,72 \%$ pada pertemuan 2 menjadi $84,72 \%$. Indikator menyatakan ulang sebuah konsep pada pertemuan 1 diperoleh data sebesar $73,89 \%$ meningkat $11,11 \%$ pada pertemuan 2 menjadi $85,00 \%$. Perolehan skor pada indikator mengklasifikasikan obyek-obyek menurut sifat-sifat tertentu (sesuai dengan konsepnya) pada pertemuan 1 sebesar $71,19 \%$ meningkat $10 \%$ pada pertemuan 2 menjadi 81,19\%. Indikator menyajikan konsep dalam berbagai bentuk representasi matematis pada pertemuan 1 sebesar $73,81 \%$ meningkat $6,67 \%$ pada pertemuan 2 menjadi $80,48 \%$. Peningkatan perolehan presentase rata-rata dicapai pada indikator mengembangkan syarat perlu dan syarat cukup suatu konsep pada pertemuan 1 sebesar 70,21\% meningkat $7,08 \%$ menjadi $77,29 \%$ pada pertemuan 2. Pada pertemuan 1 diperoleh presentase rata-rata sebesar $72,08 \%$ pada indiktor menggunakan, memanfaatkan, dan memilih prosedur atau operasi tertentu meningkat $5,84 \%$ menjadi $77,92 \%$ pada pertemuan 2 . Pada pertemuan 1 diperoleh presentase rata-rata sebesar $71,67 \%$ pada indikator mengaplikasikan konsep atau algoritma pemecahan masalah meningkat $6,25 \%$ menjadi $77,92 \%$ pada pertemuan 2 . Hal ini berarti semua aspek kemampuan pemahaman siswa mengalami peningkatan dan telah mencapai indikator ketercapaian tindakan.

Guru mengupayakan perbaikan pembelajaran dengan cara pemanfaatan tutor sebaya pada setiap kelompok. Jika semua siswa terlibat aktif dalam pemecahan masalah, maka diharapkan hasil belajar siswa akan meningkat. Hal ini sependapat dengan Suprijono (2009:128) bahwa model pembelajaran Student Facilitator and Explaining (SFAE) adalah model yang melibatkan keaktifan siswa Model pembelajaran Student Facilitator and Explaining (SFAE) melatih siswa untuk mempresentasikan ide atau pendapat pada peserta didik lainnya yaitu ide yang berupa bagan/peta konsep dari materi pelajaran.

Pada siklus I hasil belajar ranah kognitif siswa belum bisa dikatakan berhasil dan belum memenuhi kriteria ketuntasan. Hal tersebut dikarenakan pembagian kelompok yang baru disampaikan pada pertemuan pertama dan siswa disuruh duduk sesuai dengan kelompoknya masing-masing, membuat keributan dan menyita waktu yang sudah dialokasikan. Selain itu siswa belum terbiasa dengan model Student Facilitator and Explaining (SFAE), kebanyakan siswa masih merasa bingung bagaimana membuat konsep sehingga guru harus membimbing secara khusus.

Dari kekurangan pada siklus I maka disusunlah rencana tindakan pada siklus II dengan melakukan perbaikan, yaitu guru mengarahkan siswa pada pertemuan selanjutnya sebelum pembelajaran dimulai sudah harus duduk sesuai dengan kelompoknya masing-masing. Kemudian guru memberi tugas mengerjakan soal untuk dikumpulkan pada pertemuan berikutnya. Guru menghimbau siswa pada pertemuan selanjutnya untuk lebih mempersiapkan diri dalam menerima pelajaran.

Pada siklus II hasil belajar siswa mengalami peningkatan. Hal ini dikarenakan alokasi waktu sudah sesuai dengan alokasi waktu yang sudah dietntukan dan siswa sudah terbiasa dengan model pembelajaran Student Facilitator and Explaining (SFAE). Jadi, dapat disimpulkan bahwa model Student Facilitator and Explaining (SFAE) yang melibatkan siswa secara langsung sebagai fasilitator bagi siswa yang lain dapat meingkatkan hasil belajar. Hal ini bersesuaian dengan kelebihan dari model Student Facilitator and Explaining (SFAE) yaitu dapat memperluas wawasan siswa melalui kegiatan saling bertukar informasi, pendapat dan pengalaman serta mendorong tumbuh dan berkembangnya potensi berpikir kritis siswa secara optimal.

Pada siklus I hasil belajar ranah afektif belum memenuhi kriteria ketuntasan. Ketika proses pembelajaran berlangsung ada beberapa siswa yang berbicara sendiri dan membuat gaduh. Selain itu ada siswa yang berpangku tangan kepada siswa yang lain. Oleh karena itu pada siklus II diperbaiki dengan memberi teguran dan motivasi berupa penghargaan berupa tambahan nilai bagi kelompok yang kompak dan hasil kerjanya bagus dengan menyampaikan bahwa berhasil/tidaknya kelompok tergantung dari anggotanya. Menjelaskan kepada siswa 
bahwa jika mereka tidak meperhatikan dan tidak mengikuti jalannya diskusi maka mereka tidak akan menguasai materi yang nantinya tidak dapat menjawab pertanyaan. Sehingga pada siklus II dapat meningkatkan hasil belajar. Hal tersebut membuktikan bahwa model pembelajaran Student Facilitator and Explaining (SFAE) dapat meningkatkan hasil belajar.

Pada siklus I hasil belajar ranah kognitif belum bisa dikatakan berhasil karena belum memenuhi kriteria ketuntasan. Hal tersebut dikarenakan pada saat pelaksanaan pembelajaran ada beberapa siswa yang pasif, karena siswa merasa tidak bisa dan berpangku tangan pada siswa lain dalam satu kelompok. Ketika presentasi tidak ada siswa yang mau maju karena malu, sehingga guru harus menujuk salah satu dari murid. Ketika ditunjuk siswa tetap menolak karena takut ditertawakan atau dimarahi jika salah, akhirnya dengan arahan dari guru siswa bersedia maju.Siswa sedikit yang bertanya dan banyak yang tidak bisa menjawab pertanyaan, hal itu karena mereka belum terbiasa dengan model pembelajaran Student Facilitator and Explaining (SFAE).

Pada siklus II guru memberi arahan bahwa siswa yang akan presentasi dan yang akan diberi pertanyaan oleh guru akan dipilih secara acak. Bagi siswa yang tidak aktif dalam diskusi dan tidak serius dalam menguasai materi, tidak akan mampu presentasi dan menjawab pertanyaan ketika ditunjuk guru karena tidak menguasai materi. Bagi siswa yang berlaku seperti itu akan dikurangi nilainya dan bagi yang aktif dan mampu membuat pertanyaan maupun menjawab pertanyaan akan ditambah nilainya. Sehingga menjadikan siswa berusaha untuk aktif dan berusaha menguasai materi karena merasa takut jika tidak bisa ketika ditunjuk. Akan tetapi ketika disuruh presentasi siswa tetap malu-malu untuk maju, takut jika salah. Guru memotivasi dengan memberi penghargaan nilai bagi yang presentasi maupun yang bertanya, siswa tetap masih tidak mau maju sehingga guru memotivasi kepada siswa bahwa mereka pasti bisa, tidak akan ditertawakan dan tidak akan dimarahi, siswa yang lain juga belum tantu paham, dan bisa jadi mereka salah satu dari yang paham dan bisa berbagi ilmu dengan teman sekelas sehingga siswa yang lain ikut menjadi paham. Dari hal itulah akhirnya ada beberapa siswa yang mau maju tanpa ditunjuk oleh guru dan banyak yang aktif bertanya.Sehingga pada siklus II hasil belajarnya dapat memenuhi kriteria ketuntasan.

\section{Simpulan}

Hasil penelitian menunjukkan adanya peningkatan kemampuan pemahaman matematika pada siklus I diperoleh presentase rata-rata siswa sebesar $64,06 \%$ dengan kriteria cukup meningkat menjadi $76,35 \%$ dengan kriteria baik. Hasil penelitian diperoleh rata-rata hasil belajar kognitif siswa pada siklus I sebesar 73,60 dengan ketuntasan klasikal 66,67\%. Rata-rata hasil belajar kognitif siswa pada siklus II sebesar 81,83 dengan ketuntasan klasikal $86,67 \%$. Adapun rata-rata hasil belajar afektif siswa pada siklus I sebesar 73,00 dengan ketuntasan klasikal 63,33\%. Rata-rata hasil belajar afektif siswa pada siklus II sebesar 81,17 dengan ketuntasan klasikal 90\%. Sedangkan rata-rata hasil belajar psikomotorik siswa pada siklus I sebesar 69,72 dengan ketuntasan klasikal 60\%. Rata-rata hasil belajar psikomotorik siswa pada siklus II sebesar 82,78 dengan ketuntasan klasikal 83,33\%.

Berdasarkan hasil penelitian dan pembahasan dapat disimpulkan bahwa penerapan model Student Facilitator and Explaining (SFAE) pada materi sistem persamaan linear dua variabel di kelas VIII-HSMP Negeri 4 Madiun dapat meningkatkan kemampuan pemahaman dan hasil belajar siswa baik ranah kognitif, ranah afektif dan ranah psikomotorik. Peningkatan ini dapat dilihat dari kenaikan nilai rata-rata dan ketuntasan belajar secara klasikal dari siklus I ke siklus II. 


\section{DAFTAR RUJUKAN}

Arikunto, Suharsimi, dkk. 2006. Penelitian Tindakan Kelas. Jakarta: Bumi Aksara

Depdiknas. 2003. Materi Pelatihan Pembelajaran Kontekstual Guru Bidang Studi Matematika. Surabaya. Dinas Pendidikan dan Kebudayaan Propinsi Jawa Timur.

Dimyati \& Mudjiono. 2002. Belajar dan Pembelajaran. Jakarta: PT Rineka Cipta

Hudoyo Herman. 2010. Pengembangan Kurikulum dan Pelaksanaannya di depan kelas. Surabaya: Usaha Nasional

Kasihani K. E Suyanto. 2007. Pendekatan Metode Teknik Pembelajaran. Malang: Universitas Negeri Malang

Masitoh, Siti, dkk. 2011. Pembelajaran Aktif Inovatif dan Menyenangkan (PAIKEM). Universitas Negeri Surabaya: Surabaya

Matematika Kontektual. 2006. Buku Pegangan Guru Matematika Kontektual kelas IX. 2006 Jakarta: literatur Media Sukses

Sagala, Syaiful. 2011. Konsep dan Makna Pembelajaran. Bandung:Alfabeta

Saiful Rahman, Yoto, Syarif S, Suparti. 2006. Penelitian Tindakan Kelas dan Penulisan Karya Ilmiah. Surabaya: SIC Surabaya

Slavin, R.E. 2008. Cooperative Learning : Teori, Riset, dan Praktik (terjemahan). Nusa Media: Bandung

Sujana. 2001. CBSA Dalam Proses Belajar Mengajar. Bandung, Cemara 